\title{
Control of Saltcedar by Subsurface Placement of Herbicides
}

\author{
E.B. HOLLINGSWORTH, P.C. QUIMBY, JR., and D.C. JARAMILLO
}

\begin{abstract}
A root plow modified for deep subsurface placement of herbicides effectively controlled saltcedar (Tamarix ramosissima Ledeb.). One operation, preferably in the spring, which severed the tap root 35 to $60 \mathrm{~cm}$ below the soil surface and simultaneously applied any of several herbicides at the same depth increased saltcedar kill by more than $100 \%$ over that of root cutting alone. Residual herbicides, including uracils, substituted ureas, $2,3,6-$ TBA, picloram, dicamba, and karbutilate, applied with the root plow consistently controlled saltcedar with a single treatment. Phenoxy herbicides showed initial activity against saltcedar but did not persist long enough to satisfactorily kill late sprouting, previously quiescent buds. Two arsenicals and dichlobenil were ineffective for saltcedar control.
\end{abstract}

Saltcedar (Tamarix spp.) originally attracted attention through its rapid invasion of channels and floodplains of streams in the southwestern United States. Robinson (1965), Case (1969) and Horton et al. (1976) reported details of this invasion, the disadvantages of saltcedar, and early organized efforts directed at its control. Long-term control required repeated chemical and mechanical treatments. Foliar sprays usually defoliated and often killed the aerial parts of saltcedar but seldom killed the root system. Bud resprouting and plant survival after chemical or mechanical control efforts were common because of poor basipetal translocation of herbicides, deep extensive root systems, and resistant root crown buds. Occasionally, resprouting was delayed for 12 to 24 months after treatment. This delayed recovery often led to false reports of good chemical control during early studies because the investigator did not allow sufficient time before making a final evaluation of saltcedar control.

Field observations supported by greenhouse studies (Quimby et al. 1977) indicate that herbicides available to the roots are readily assimilated and translocated in saltcedar. Compounds that are ineffective as foliar sprays often provide permanent control where available through the roots. However, soil and climatic conditions in the arid southwest may prevent soilapplied herbicides from reaching the root zone. In addition, saltcedar has a deep, active root system near the water table but usually has relatively few active, sorptive roots near the surface where the herbicides are likely to remain because of limited leaching. Partially buried stem segments of saltcedar following

At the time of the study, the authors were botanist, plant physiologist, and agricultural research technician. Science and Education Administration, Federal Research, U.S. Department of Agriculture. Middle Rio Grande Branch Experiment Station, New Mexico State Liniversity, Los Lunas 87031.

Hollingsworth and Quimby are presently with the Southern Weed Science Laboratory, SEA-FR, U.S. Dep. of Agri., Stoneville, Miss. 38776. Jaramillo is presently biological laboratory technician, Animal Parasite Research Laboratory, SEA-FR. U.S. Dep. Agr., Albuqueryuc. N.M. 87103.

The report represents cooperative investigations of the SEA-FR. U.S. Dep. Agr., and the New Mexico Agr. Exp. Sta.

Manuscript received November 23, 1977 attempts at mechanical control take root readily in moist soil, increasing survival capability.

Twenty years after the first large-scale attempt to control saltcedar, the problem of getting phytotoxic amounts of herbicides into saltcedar plants had not been solved. Since natural conditions were not favorable for getting adequate amounts of herbicides into the deeper root zone, a mechanical injection method was sought. Development of a method for deep placement of herbicide, utilizing a standard root plow, was initiated in 1969. Modification of the equipment and the method have been described by Hollingsworth et al. (1973). Briefly, the operation involves cutting the tap root of saltcedar at a selected depth and simultaneously applying a herbicide with a spray boom attached to the rear edge of the plow blade. The remaining active roots in or immediately above the layer of herbicide readily absorb it.

The objective of this study was to determine the response of saltcedar, specifically Tamarix ramosissima Ledeb., to a variety of herbicides applied by the root plow injection method.

\section{Materials and Methods}

Herbicides were applied with either a 1.22 or $2.44-\mathrm{m}$ wide root plow. All treatments were duplicated and the data were subjected to analyses of variance for a randomized complete block design. Means were compared by Duncan's multiple range test at the $95 \%$ level of probability.

The first experiment was established on the Cimarron River floodplain near Ashland, Kansas, on June 19, 1969. The area consisted of mildly saline, subirrigated, moderately well-drained sandy loam soil. The water table was 72 to $96 \mathrm{~cm}$ deep and regrowth saltcedar from established root crowns averaged $3 \mathrm{~m}$ tall. The average annual rainfall is about $56 \mathrm{~cm}$ and rainfall between June 19 and October 22 was 42

Table 1. Percentage saltcedar killed 28 months after application of herbicides at an average depth of $50 \mathrm{~cm}$ by the root-plow method in June 1969, Cimarron River floodplain near Ashland, Kansas.

\begin{tabular}{|c|c|c|c|}
\hline & & \multicolumn{2}{|c|}{ Control (\% kill) } \\
\hline \multicolumn{2}{|l|}{ Treatment } & & Uncut strip \\
\hline Herbicide & $\begin{array}{c}\text { Rate } \\
(\mathrm{kg} / \mathrm{ha})\end{array}$ & $\begin{array}{l}\text { Root-plowed } \\
\text { swath }^{1}\end{array}$ & $\begin{array}{l}\text { between } \\
\text { swaths }\end{array}$ \\
\hline Monuron & 5.6 & $100 \mathrm{a}$ & 50 \\
\hline Diuron & 5.6 & $98 \mathrm{a}$ & 80 \\
\hline Picloram: $2,4,5-\mathrm{T}(1: 4)$ & 4.5 & $95 \mathrm{a}$ & 50 \\
\hline Dicamba & 9 & $92 \mathrm{a}$ & 15 \\
\hline 2, 4-D Alk & 9 & $88 \mathrm{a}$ & 0 \\
\hline None (root-plowed check) & - & $54 \mathrm{~b}$ & 0 \\
\hline
\end{tabular}

' Based on count of 300 plants per plot in duplicate per treatment; means followed by a letter in common are not significantly different at the 0.05 level of probability according to Duncan's multiple range test. 
$\mathrm{cm}$. The 2.44-m wide plow blade was operated at a depth of $50 \mathrm{~cm}$ in 0.2 ha plots and the herbicides were applied in 900 liters/ha of water. The percentage of saltcedar kill was determined 28 months after treatment by counting 300 plants per plot within the plow swaths and comparing live and dead plants. In addition, all plants were counted in several uncut narrow strips between plow swaths and the percentage plant kill determined. Statistical analysis was not performed on the data from uncut strips.

A second experiment was established on the Rio Grande floodplain near Bernardo, New Mexico, on July 30, 1970. The sandy clay loam was highly saline and poorly drained. Regrowth from the crowns of saltcedar that had been burned or mowed periodically for several years ranged from 1.5 to $2 \mathrm{~m}$ tall. The water table was 48 to $72 \mathrm{~cm}$ deep and the $1.22-\mathrm{m}$ wide plow blade was operated 30 to $40 \mathrm{~cm}$ deep. The herbicides were applied in 900 liters/ha of water to 0.01-ha plots. An estimate of the percentage of treated plants showing regrowth was made periodically. Two of these observations, 2 and 12 months after treatment, are shown in Table 2. Five years after treatment, the surviving plants in each plot were counted and compared with the total number of plants at the time of treatment (Table 2).

Table 2. Saltcedar regrowth within 1 year and percentage plants killed 5 years after application of herbicides at an average depth of $35 \mathrm{~cm}$ by the root-plow method in July 1970, Rio Grande floodplain, Bernardo, New Mexico.

\begin{tabular}{lcccc}
\hline \hline \multicolumn{1}{c}{ Treatment } & & \multicolumn{2}{c}{ Regrowth $^{1}(\%)$} & \\
Herbicide & $\begin{array}{c}\text { Rate } \\
(\mathrm{kg} / \mathrm{ha})\end{array}$ & $\begin{array}{c}2 \\
\text { months }\end{array}$ & $\begin{array}{c}12 \\
\text { months }\end{array}$ & $\begin{array}{c}\text { Control } \\
\text { after }^{2} \% \text { years }\end{array}$ \\
\hline Bromacil & 11 & 75 & 8 & $99 \mathrm{a}$ \\
Dichlobenil + picloram & $5+5$ & 25 & 4 & $98 \mathrm{a}$ \\
Terbacil & 11 & 75 & 8 & $98 \mathrm{a}$ \\
Dichlobenil + dicamba & $5+5$ & 15 & 3 & $97 \mathrm{a}$ \\
Monuron & 11 & 85 & 18 & $95 \mathrm{a}$ \\
2,3,6-TBA & 11 & 30 & 15 & $91 \mathrm{a}$ \\
Picloram + dicamba & $5+5$ & 20 & 4 & $90 \mathrm{a}$ \\
Dicamba & 11 & 45 & 20 & $90 \mathrm{a}$ \\
Picloram + amitrole & $5+5$ & 45 & 5 & $89 \mathrm{a}$ \\
Dichlobenil & 11 & 40 & 38 & $85 \mathrm{ab}$ \\
Silvex PGBE & 11 & 45 & 25 & $83 \mathrm{ab}$ \\
2,4-D Alk + 2,4-D PGBE & $5+5$ & 25 & 25 & $80 \mathrm{ab}$ \\
Silvex K-salt & 11 & 40 & 28 & $79 \mathrm{ab}$ \\
None & & & & \\
Root-plowed check & - & 70 & 47 & $65 \mathrm{~b}$ \\
Unplowed check & - & 100 & 100 & $0 \mathrm{c}$ \\
& & & &
\end{tabular}

Two visual estimates for each treatment, hence no statistical analysis

- Based on count of total plants per plot in duplicate plots per treatuent; means followed by a letter in common are not significantly different a the 0.05 level of probability according to Duncan's multiple range test

A third experiment was established on the Rio Grande floodplain near Bernardo, New Mexico, on April 8, 1971. Soil characteristics, saltcedar regrowth, plot size, and treatment procedures were similar to those described in the second experiment. The $1.22-\mathrm{m}$ wide plow blade was used to apply the herbicides. The percentage plant kill was determined at 6 months and 4.5 years after treatment by comparing surviving plants with the total number of plants per plot at the time of herbicide application.

A fourth experiment was established on the New Mexico Game and Fish Commission refuge at Bernardo, New Mexico, on August 4, 1971. The soil was highly saline, subirrigated, sandy clay loam. The well-established, dense, 10- to 15-year-old saltcedar plants had been periodically mowed or burned, and regrowth since mowing 5 months earlier was 60 to $90 \mathrm{~cm}$ tall. The saltcedar density had reduced the native grass stand to $10 \%$ or less throughout the experimental area. The water table was 72 to $84 \mathrm{~cm}$ deep and the $2.44-\mathrm{m}$ wide plow blade was operated at a $60 \mathrm{~cm}$ depth. The herbicides were applied in 400 liters/ha of water to 0.16 -ha plots. The percent saltcedar control was determined 4 years after treatment by recording the number of surviving plants out of 600 plants examined per plot (Table 4). Reinfestation by two of the more prominent native grasses, desert saltgrass [distichlis stricta (Torr.) Rydg.] and alkali sacaton [Sporobolus airoides (Torr.)], was also noted. The extent of each grass species was estimated by two individuals and their results were averaged to give the percent infestation.

\section{Results}

The first two experiments with the root-plow injection technique required minor adjustments in the equipment and operation. It was necessary to adjust the blade angle or pitch to keep the plow in the soil with a minimum of power drag. The spray system provided uniform herbicide application without nozzle clogging. However, when the saltcedar plants were too large to pass easily through the throat of the plow, occasional stops were necesary to remove the obstruction. Most troublesome for the larger plow (2.44-m wide blade) were plants more than $3 \mathrm{~m}$ tall and for the smaller plow (1.22-m wide blade) those more than $2 \mathrm{~m}$ tall. This difficulty was resolved by crushing, burning, or otherwise reducing the size of large saltcedar prior to plowing.

A second operational problem not anticipated was the need for adjacent plow swaths to join or slightly overlap. If the taproot of saltcedar was not severed the plant often survived. Such plants were usually located in a narrow unplowed strip between plow swaths. Survival of uncut plants was further dependant upon the type of herbicide used in adjacent plow swaths. Herbicides with short residual activity, such as the phenoxy compounds, usually did not control uncut plants. Substituted ureas or the uracils provided longer residual activity and often killed plants in the unplowed strip even though the taproot had not been severed.

Several herbicides killed 35 to $45 \%$ more of the saltcedar plants than did root plowing alone (Table 1). The percentage of plants killed was lower in the uncut strips than in the adjacent root plowed swaths, reflecting an increase in survival ability of those plants whose roots were not severed. Plants in uncut strips adjacent to plow swaths treated with 2,4-D [(2,4-dichlorophenoxy) acetic acid] and dicamba (3,6-dichloro-o-anisic acid) were least affected; but 50 and $80 \%$, respectively, of uncut plants adjacent to monuron [3-p-chlorophenyl-1,1-dimethylurea]and diuron [3-(3,4-dichlorophenyl)-1,1-dimethylurea]-treated swaths were dead after more than 2 years. Additional observation revealed no apparent increase in saltcedar infestation in these plots 7 years after treatment.

Saltcedar responded dramatically to severing of the root system in July when the plants were apparently under moisture stress. After root plowing, leaves withered and bleached severely within 24 hours. Defoliation was complete within a few days. Despite this dramatic initial response, $35 \%$ of the plants survived in the root-plowed plots which were not treated with herbicide (Table 2). Two months after treatment, regrowth was extensive in several plots. After the plants had experienced a winter and the herbicides had apparently been more fully assimilated, the level of regrowth was reduced in many treatments. After 5 years, one application of each herbicide treatment had killed $80 \%$ or more of the plants. Nine treatments, which killed $89 \%$ or more plants, were significantly better ( $0.05 \%$ level) than root plowing alone (Table 2 ).

The third experiment compared the activity of representative compounds from nine classes of herbicides: substituted ureas, picolinic acid, uracil, anisic acid, benzonitrile, benzoic acid, phenoxyacetic acid, carbamate, and arsenical. Several herbicides were evaluated in combination with other herbicides. 
When evaluated 4.5 years after application, nine treatments had killed 85 to $100 \%$ of the saltcedar, a significantly higher percentage kill than that for the other 14 treatments (Table 3). Diuron, picloram (4-amino-3,5,6-trichloropicolinic acid), bromacil (5-bromo-3-sec-butyl-6-methyluracil), and dicamba applied at $9 \mathrm{~kg} / \mathrm{ha}$ killed $100,99,98$, and $98 \%$ respectively of the saltcedar. Karbutilate (tert-butylcarbamic acid ester with 3-(m-hydroxyphenyl)-1,1-dimethylurea], a carbamate with urea linkage, also provided good control ( $90 \%$ kill). Combining the various phenoxy compounds with picloram did not increase control over that resulting from picloram alone, and dicamba with dichlobenil (2,6-dichlorobenzonitrile) was less effective than dicamba alone. All herbicide treatments except the propyleneglycol butylether ester of silvex [2-(2,4,5-trichlorophenoxy) propionic acid], dichlobenil alone, cacodylic acid (hydroxydimethylarsine oxide), and MAA (methanearsonic acid) were significantly more effective than root plowing alone (Table 3).

Table 3. Control of saltcedar 0.5 and 4.5 years after application of herbicides at an average depth of $35 \mathrm{~cm}$ by the root plow method in April 1971, Rio Grande floodplain, Bernardo, New Mexico.

\begin{tabular}{|c|c|c|c|}
\hline \multicolumn{2}{|l|}{ Treatment } & \multicolumn{2}{|c|}{ Control $^{1}(\%$ kill $)$ after } \\
\hline Herbicide & Rate (kg/ha) & 0.5 year & 4.5 years \\
\hline Diuron & 9 & $45 \mathrm{fg}$ & $100 \mathrm{a}$ \\
\hline Picloram & 9 & $100 a$ & $99 a$ \\
\hline Bromacil & 9 & $75 b$ & $98 a b$ \\
\hline Picloram:2,4-D (1:2) & 9 & $98 \mathrm{a}$ & $98 a b$ \\
\hline Dicamba & 9 & $90 a$ & $95 \mathrm{ab}$ \\
\hline Picloram:2,4,5-T (1:1) & 9 & $90 a$ & $95 \mathrm{ab}$ \\
\hline Picloram:2,4,5-T (1:4) & 9 & $90 a$ & $95 \mathrm{ab}$ \\
\hline Karbutilate & 17 & 65 bcd & $90 \mathrm{abc}$ \\
\hline Dichlobenil + dicamba & $5+5$ & $75 b$ & 85 abcd \\
\hline 2,4-D DMA & 11 & 60 cde & 80 bcde \\
\hline Silvex BE & 11 & $45 \mathrm{fg}$ & 80 bcde \\
\hline $2,3,6-\mathrm{TBA}$ & 9 & $70 \mathrm{bc}$ & 80 bcde \\
\hline 2,4-D Alk + 2,4-D BE & $5+5$ & 60 cde & 75 cde \\
\hline Dicamba:2,4-D & 11 & $60 \mathrm{cde}$ & $75 \mathrm{cdc}$ \\
\hline $2,4-\mathrm{D} \mathrm{BE}$ & 11 & $50 \mathrm{efg}$ & $75 \mathrm{cde}$ \\
\hline Silvex K-salt & 11 & $55 \mathrm{def}$ & 70 def \\
\hline $2,4-\mathrm{D} \mathrm{Alk}$ & 11 & $60 \mathrm{cde}$ & 70 def \\
\hline $2,4-\mathrm{D}: 2,4,5-\mathrm{T}$ & 11 & $40 \mathrm{gh}$ & 65 efg \\
\hline Silvex PGBE & 11 & $25 \hat{\mathrm{i}}$ & $55 \mathrm{fgh}$ \\
\hline Dichlobenil & 11 & $10 \mathrm{j}$ & 50 ghi \\
\hline None (root-plowed check) & - & $30 \mathrm{hi}$ & $40 \mathrm{hi}$ \\
\hline Cacodylic acid & 9 & $0 \mathrm{i}$ & $40 \mathrm{hi}$ \\
\hline MAA & 9 & $5 \mathrm{j}$ & $35 \mathrm{i}$ \\
\hline
\end{tabular}

\footnotetext{
${ }^{1}$ Based on count of total plants per plot in duplicate plots per treatment; means followed by a letter in common are not significantly different at the 0.05 level of probability atcording to Duncan's multiple range test.
}

The herbicides used in the final experiment were selected primarily because of their residual weed-control properties and satisfactory performance in earlier experiments. Dichlobenil is an exception in that it controlled saltcedar satisfactorily in the second experiment but not in the third.

Picloram was as effective alone as when it was used at $6 \mathrm{~kg} / \mathrm{ha}$ in combination with dichlobenil (Table 4). Three $\mathrm{kg} / \mathrm{ha}$ of picloram combined with dichlobenil provided significantly less saltcedar kill than any of the other herbicide treatments. All other treatments, with herbicides, killed at least $85 \%$ of the plants which was significantly more than the $40 \%$ kill by root plowing alone.

Release from the dense competition of saltcedar following herbicide application permitted recovery of suppressed grasses in those instances where they were not adversely affected by the herbicides (Table 4). Bromacil and diuron were most damaging
Table 4. Control of saltcedar and the response of two native grasses 4 years after application of herbicides at an average depth of $60 \mathrm{~cm}$ by the root-plow method in August 1971, Rio Grande floodplain, Bernardo, New Mexico.

\begin{tabular}{|c|c|c|c|c|c|}
\hline \multirow[b]{2}{*}{ Herbicide } & \multirow[b]{2}{*}{$\begin{array}{c}\text { Rate } \\
(\mathrm{kg} / \mathrm{ha})\end{array}$} & \multicolumn{2}{|c|}{ Saltcedar } & \multicolumn{2}{|c|}{$\begin{array}{c}\text { Percent infestation } \\
\text { of indigenous grasses }\end{array}$} \\
\hline & & $\begin{array}{l}\text { Surviving } \\
\text { plants }\end{array}$ & $\begin{array}{l}\text { Control }^{1} \\
\text { (\% kill) }\end{array}$ & $\begin{array}{c}\text { Desert } \\
\text { saltgrass }\end{array}$ & $\begin{array}{l}\text { Alkali } \\
\text { sacaton }\end{array}$ \\
\hline Bromacil & 7 & 4 & $99 a$ & 20 & 10 \\
\hline Diuron & 6 & 2 & $99 a b$ & 60 & 0 \\
\hline Diuron + picloram & $3+3$ & 12 & $98 \mathrm{ab}$ & 70 & 20 \\
\hline Picloram & 7 & 21 & $97 \mathrm{ab}$ & 70 & 30 \\
\hline Dichlobenil + picloram & $6+6$ & 25 & $96 a b$ & 70 & 20 \\
\hline Dichlobenil+dicamba & $6+6$ & 30 & $95 \mathrm{ab}$ & 80 & 20 \\
\hline Dicamba + picloram & $6+6$ & 60 & $90 \mathrm{bc}$ & 90 & 0 \\
\hline Dicamba & 7 & 90 & $85 c$ & 80 & 15 \\
\hline Dichlobenil + picloram & $6+3$ & 180 & $70 \mathrm{~d}$ & 80 & 10 \\
\hline \multicolumn{6}{|l|}{ None } \\
\hline Root-plowed check & - & 363 & $40 \mathrm{e}$ & 50 & 0 \\
\hline Unplowed check & - & 600 & $0 \mathrm{f}$ & 10 & 0 \\
\hline
\end{tabular}

' Based on a count of 600 plants per plot in duplicate plots per treatment; means followed by a letter in common are not significantly different at the 0.05 level of probability according to Duncan's multiple range test.

to desert saltgrass, the more prominent of the two species. The other treatments permitted a large increase in desert saltgrass infestation over that of the unplowed check. The presence of alkali sacaton was too variable within and betwecn plots to establish a clear pattern of response to the various herbicides.

\section{Discussion}

This study shows that a single treatment combining root plowing and subsurface application of certain herbicides will satisfactorily control saltcedar. The percentage kill is higher than for root cutting alone and a larger, more permanent control is possible than with one application of a herbicide alone.

Picloram and dicamba were the most effective herbicides for control of saltcedar and were less damaging to the native grasses. The flush of regrowth and subsequent increase in kill from 2 to 12 months (Table 2) indicates a need to wait at least 1 year after treatment before making a final determination of saltcedar response.

Use of root cutting concurrent with subsurface herbicide application may be the most effective and economical method of treatment for saltcedar on sites where the equipment can be operated. Cutting, burning, or crushing large saltcedar a few weeks before root plowing facilitates the use of this method. The percentage kill of saltcedar from the combined treatment, using various herbicides, was more than double that from root plowing alone. In the earlier experiments, the advantage of the herbicide plus root plow treatment was less apparent because of the presence of surviving plants (in strips between plow swaths) whose root escaped cutting.

Many herbicides can kill saltcedar when they enter through the root system, but the root system is the plant part best protected by nature from exposure to herbicides. Use of the root plow for subsurface application not only places the herbicide close to the roots, but it also cuts off the lower roots and, thereby, all access to moisture and nutrients except by the remaining roots near the herbicide-treated soil.

Variation between treatments in the amount of saltcedar regrowth at 2 months (Table 2) and of control at 0.5 year (Table 3) suggests a difference in herbicide absorption and translocation and/or differential susceptibility to herbicides. Prolific 
shoot formation from previously quiescent buds is often apparent a few weeks after treatment of saltcedar with a herbicide. Perhaps the buds must sprout and become active before the herbicide can be absorbed. Compounds that provide only a short-term residual action may dissipate before all viable buds become active. The more persistant herbicides such as bromacil, terbacil (3-tert-butyl-5-chloro-6-methyluracil), diuron, and monuron [3-( $p$-chlorophenyl)-1, 1-dimethylurea] provide less early control and equal or better final control than the other treatments (Tables 2 and 3). This indicates that herbicides with longer residual action may be a better selection for overcoming herbicides would also be an advantage where time may be required for the root system to grow into contact with the herbicide or the herbicide to diffuse into the root zone. Such a time requirement may have been responsible for the delayed kill of saltcedar plants in the uncut strips between plow swaths.

Use of the root-plow for subsurface application of herbicides offers the following advantages over traditional means of saltcedar control: (1) a single treatment any time during the growing season places the herbicide so that its activity is least affected by rainfall, wind, or temperature change. This type of application is relatively safe with regard to drift or to direct contact with wildlife. (2) The method can be used where saltcedar removal would be most beneficial, i.e., on flat land for row crops or flat or rolling ground for forage crops and grazing. (3) When properly done, the mechanical operation does not excessively disturb the sod or soil surface. Established grasses survive and quickly benefit from the release from saltcedar competition. Livestock grazing and mowing can continue after treatment. (4) The application cost, though initially higher than that for some traditional treatments, is lower than that for the separate mechanical and chemical operations, repeated over several years, that would be necessary for equal control.

Development of the root plow method of herbicide injection covered a period of 3 years. Unfortunately, the federal research station at Los Lunas, New Mexico, was terminated before early screening experiments could be completed and optimum herbicide rates determined for inclusion in repeated experiments. The results of four experiments have been presented because the preliminary evidence indicates that the root plow method of herbicide injection for saltcedar control has merit and deserves further refinement.

\section{Literature Cited}

Case, F.O. 1969. History of Phreatophyte Subcommittee. Minutes of the Phreatophyte Subcommittee, Pacific Southwest Interagency Committee 3:224-230.

Hollingsworth, E.B., P.C. Quimby, Jr., and D.C. Jaramillo. 1973. Root plow herbicide application as a new incorporation technique. Weed. Sci. 21:128-130.

Horton, J.S. 1976. Management of moist site vegetation for water: past history, present status, and future needs. Special Report of the Vegetation Management Technical Subcommittee, Pacific Southwest Interagency Committee. $41 \mathrm{p}$

Quimby, P.C., Jr., E.B. Hollingsworth, and R.L. McDonald. 1977. Techniques for greenhouse evaluation of herbicides on saltcedar. Weed Sci. 25:1-4.

Robinson, T.W. 1965. Introduction, spread, and areal extent of saltcedar (Tamarix) in the western states. U.S. Geol. Surv. Prof. Pap. 491-A. 12 p.

A truly international group of authors discusses rangelands of the world-their plants, soils, management. ecosystem, animals, inventory, economics, and the societies that live on them. The book includes author and general indices, original illustrations by Harold F. Heady, and minutes of the business meetings of the historic congress. Hard-bound, 742 pages $81 / 2 \times 11$ inches: $\$ 60.00$ postpaid. (For airmail include an additional $\$ 20.00$ U.S.)

Society for Range Management

2760 West Fifth Avenue

Denver, Colorado 80204

USA 